
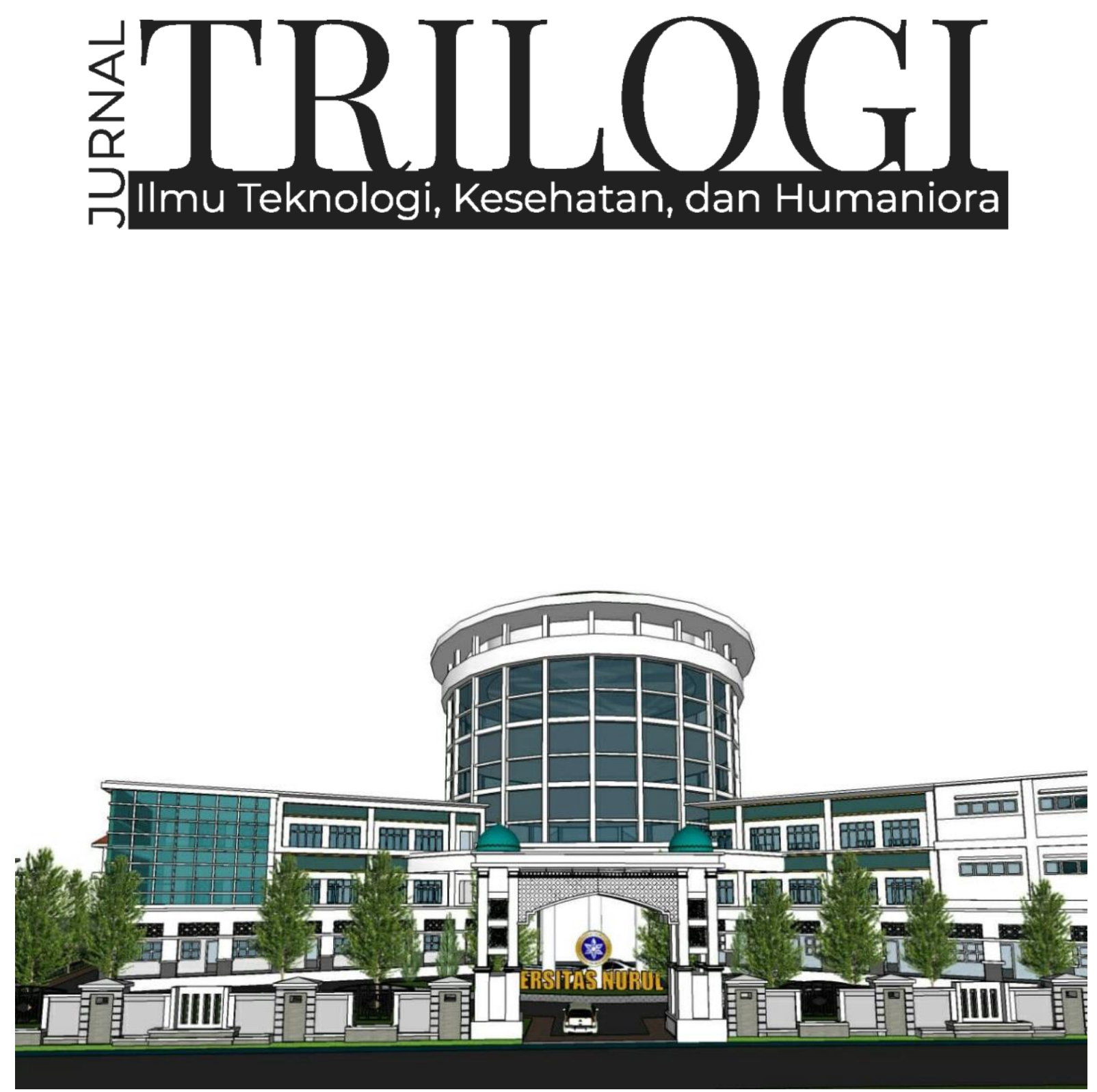

PENGEMBANGAN PENDIDIKAN DAN EKONOMI PESANTREN DI MASA PANDEMI COVID-19 


\section{犃BUOGI}

Vol. 2, No. 2, 2021

Editor in Chief

Achmad Fawaid, (SCOPUS ID: 57214837323)

\section{Managing Editors}

Hasan Baharun, (ID SCOPUS : 57200983602)

Sugiono Sugiono, (SCOPUS ID : 57199578160)

Ismail Marzuki, (SCOPUS ID: 57201500245

Subhan Rachman, (SCOPUS ID: 57192937912)

Nurul Huda, (SINTA ID: 6119615)

Syamsuri, (SINTA ID: 6116825)

Ridhatullah Assya'bani, (SINTA ID: 6200862)

\section{Peer Reviewers}

Miftahul Huda, (SINTA ID: 6171566), University of Antwerp, Belgium

Achmad Naufal Irsyadi, (SINTA ID: 6704870), Universitas Nurul Jadid, Indonesia

Gulpi Qorik Oktagalu P., (SINTA ID: 5982074) Universitas Nurul Jadid Probolinggo, Indonesia Hozairi, (SINTA ID: 166198), Universitas Islam Madura, Indonesia

Nur Hamid, (SINTA ID : 6744813), Univeristas Nurul Jadid Probolinggo, Indonesia Zainal Munir, (SINTA ID: 6672512), Universitas Nurul Jadid Probolinggo, Indonesia Sri Astutik Andayani, (SINTA ID: 6172559), Universitas Nurul Jadid Probolinggo, Indonesia Sukamto Sukamto, (SINTA ID: 5979034), Universitas Widya Gama Malang, Indonesia Deny Utomo, (SINTA ID: 6016108), Universitas Yudharta Pasuruan, Indonesia Fariz Alnizar, (SCOPUS ID: 6659824), UNUSIA Jakarta, Indonesia

Fuad Rahman, (SCOPUS ID: 57201474778), UIN Sulthan Thaha Saifuddin Jambi, Indonesia Saifuddin Zuhri Qudsy, (SCOPUS ID: 57213595165), UIN Sunan Kalijaga Yogyakarta, Indonesia Akhmad Anwar Dani, (SINTA ID: 14305), IAIN Surakarta, Indonesia

Maufur Maufur, (SINTA ID: 5989329), IAIN Kediri, Indonesia

Siti Mahmudah Noorhayati, (SINTA ID: 6726997), IAIN La Roiba Bogor, Indonesia Busro Busro, (SCOPUS ID: 57205022652), UIN Sunan Gunung Djati Bandung, Indonesia Akmal Mundiri, (SCOPUS ID: 57205059378), UNUJA Probolinggo, Indonesia

\section{Section Editor}

Ahmad Zubaidi, Universitas Nurul Jadid, Probolinggo, Indonesia 
TRILOGI: Jurnal IImu Teknologi, Kesehatan, dan Humaniora is a peer-reviewed journal, open-access journal which publishes original articles on various issues within technology, health, and social humanities, which include but are not limited to newrenewable energy, food-agriculture, health-pharmacy, transportation, informationcommunication technology, advanced-materials, maritime-infrastructre, social-artseducation, and religious studies based on academic and scientific research.

TRILOGI: Jurnal IImu Teknologi, Kesehatan, dan Humaniora seeks to publish a balanced mix of theoretical or empirical articles, case studies, review papers, comparative studies, exploratory papers, and book reviews. All accepted manuscripts will be possibly published both online and in printed forms.

Editorial Office:

TRILOGI: Jurnal IImu Teknologi, Kesehatan, dan Humaniora Lembaga Penerbitan, Penelitian, dan Pengabdian kepada Masyarakat (LP3M) Universitas Nurul Jadid, Paiton, Probolinggo, Jawa Timur, Indonesia 67291.

Phone: 088830 77077, Hp: 082318007953

Email: jurnal.trilogi@gmail.com

Website: https://ejournal.unuja.ac.id/index.php/trilogi/index 


\section{Tables of Content}

71-76

Pengaruh Metode Pembelajaran Daring dengan Aplikasi Google Classroom terhadap Hasil Belajar Siswa Madrasah Ibtidaiyah Nurul Mun'im Paiton Probolinggo

Feriska Listrianti, Lailatul Munawwaroh, Sayyidatul Arifa, Siti Aisyah

77-84

Inklusivitas dan Responsivitas Pesantren dalam Penanganan Pandemi Covid 19: Telaah Hidden Curriculum Pembelajaran di Pondok Pesantren Nurul Jadid

Zakiyah BZ, Uswatun Hasnah, Nafistur Rahmah

84-94

Integrasi Kurikulum Madrasah Diniyah dengan Lembaga Formal dalam Meningkatkan Mutu Lulusan di Sekolah Menengah Pertama (SMP) Nurul Jadid Paiton Probolinggo

Abdurrahman, Ika Fitri Anwar, Sofiya Mauliza, Nadya Afkarina

95-104

Some Issues on Time Deposit Financing: An Islamic Perspective on Mudharabah Agreement at Baitul Maal wa Tamwil (BMT) NU in Randuagung Lumajang

Saifuddin, Abdul Hafid, Hengki Wahyu Pratama

$105-110$

Analisis Pengembangan Potensi Ekonomi Keluarga melalui Unit Usaha Kapuk

Fahrudin, Iis Sa'diyah, Rizaldi Chandra Gunawan

111-117

Penguatan Ekonomi Pesantren melalui Pengembangan Ekonomi Masyarakat Pesisir: Pelajaran dari Pondok Pesantren Nurul Jadid Paiton Probolinggo

Achmad Febrianto, Muhammad Habibullah, Aksal Ilhamsyah

118-125

Prevensi Perilaku Konsumtif Persepektif Abraham Maslow dan Tri Logi Santri

Muhammad Syaiful Suib, Habibatur Rizkiyah, Fitria Nur Ain 
$126-136$

Manajemen Pengembangan Kurikulum Berorientasi pada Pembentukan Karakter

Moh Rifa'i, Fatimah Al Zahra, Abdurrahman Abdurrahman, Mukhlisin Saad

137-147

Home Industry, Kaderisasi, dan Santripreneur

Muh Hamzah, Aprilinda Dwi Kurniawati, Husnul Khotimah

148-157

Rancangan Pengelolaan Nirsampah Mandiri Skala Lembaga Pendidikan

Tirmidi, Eril Sinta Nuriyah, Rofi'ah

158-166

Parents' Knowledge and Commitment To Stimulate Child Development

Lailatul Fitriyah, Nurul Islamiyah, Auliya' Fatahillah

167-172

Implementasi Pembelajaran Akhlak Berbasis Multikultural pada Masa Pandemi di Madrasah Tsanawiyah Nurul Jadid Paiton Probolinggo

Abdullah, Yusrolana, Nur Laily

$173-183$

Implementasi Evaluasi Pembelajaran Daring (Online) melalui Home Visit

Moch Tohet, Moh. Bagus Abdillah, Adam Hakim Al Rizki

184-192

Efektivitas Pembelajaran Luring pada Mata Pelajaran Matematika selama Pandemi Covid-19

Zaenol Fajri, Sukron Junaidi, Hamdani Alfarisi 
P-ISSN: 2774-4574; E-ISSN: 2774-4582

TRILOGI, 2(2), Mei-Agustus 2021 (184-192) @2021 Lembaga Penerbitan, Penelitian, dan Pengabdian kepada Masyarakat (LP3M) Universitas Nurul Jadid Paiton Probolinggo

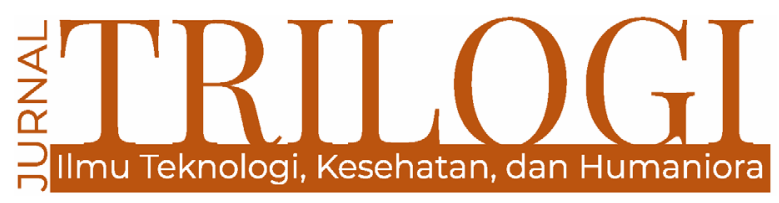

\title{
EFEKTIVITAS PEMBELAJARAN LURING PADA MATA PELAJARAN MATEMATIKA SELAMA PANDEMI COVID-19
}

\section{Zaenol Fajri}

Universitas Nurul Jadid, Probolinggo, Jawa Timur alfajri002@gmail.com

\section{Sukron Junaidi}

Universitas Nurul Jadid, Probolinggo, Jawa Timur

suju.orsevent@gmail.com

\section{Hamdani Alfarisi}

Universitas Nurul Jadid, Probolinggo, Jawa Timur

alfarisihamdani46@gmail.com

\begin{abstract}
The Indonesian Covid-19 have impacts on the system of education. To minimize the spread of viruses, learning is taken online from home. However, there were many obstacles in implementation of online learning, including at SDN Wonosuko 2 Bondowoso. First, students do not have online learning media. Second, residence of students have difficulty in getting signals. Third, math lessons are difficult to learn online. The possible solution is to carry out learning by means of luring / offline learning (the teacher comes to group learning students). The purpose of this study was to determine the effectiveness of luring learning in mathematics subjects in the $6^{\text {th }}$ grade of students of SDN Wonosuko 2 Bondowoso. The research method is descriptive-qualitative method through observation, questionnaires and interviews. The results showed that luring learning is possible to increase the effectiveness of mathematics learning in the $6^{\text {th }}$ grade students of SDN Wonosuko 2 Bondowoso and help them in recognizing subject matter during the pandemic Covid.
\end{abstract}

Keywords: Effectiveness; Offline Learning; and Mathematics 


\begin{abstract}
Abstrak
Covid-19 di Indonesia berpengaruh pada sitem pendidikan. Untuk meminimalisir penyebaran virus, pembelajaran dilakukan dari rumah secara daring. Namun, di lapangan banyak kendala pelaksanaan pembelajaran daring, termasuk di SDN Wonosuko 2 Bondowoso. Pertama, siswa tidak memiliki media belajar online. Kedua, tempat tinggal siswa kesulitan sinyal seluler. Ketiga, pelajaran Matematika sulit dipelajari secara daring. Maka, solusi terbaik tetap melaksanakan pembelajaran dengan cara luring (guru mendatangi siswa belajar berkelompok). Tujuan penelitian ini adalah untuk mengetahui efektifitas pembelajaran luring pada mata pelajaran Matematika Siswa Kelas 6 SDN Wonosuko 2 Bondowoso. Metode penelitian yang digunakan adalah metode deskriptif-kualitatif melalui observasi, angket dan wawancara. Hasil penelitian menunjukkan bahwa pembelajaran secara luring dapat meningkatkan efektivitas pembelajaran Matematika pada siswa kelas VI SDN Wonosuko 2 Bondowoso dan dapat membantu siswa dalam memamahami materi pelajaran dengan baik meskipun masih ada beberapa kendala yang dihadapi.
\end{abstract}

Katakunci: Efektifitas; Pembelajaran Luring; Matematika

\section{Pendahuluan}

Pada awal 2020, pendidikan di Indonesia mengalami hambatan dalam pelaksanaan pembelajaran, semenjak adanya Coronavirus Diseases 2019 (Mastura, \& Santaria, 2020; Halal, 2020). Dalam mengantisipasi penularan Covid-19 tersebut, pemerintah membuat kebijakan baru tentang social distancing, physical distancing dan pembatasan sosial berskala besar (PSBB) (Halal, 2020).

Covid-19 merupakan jenis penyakit baru yang proses penyebarannya sangat cepat pada manusia. Gejalanya yaitu gangguan pernapasan akut seperti demam, batuk, dan sesak napas. Masa inkubasi rata-rata 5 hari dengan masa inkubasi terpanjang 14 hari ( $\mathrm{Aji}, \mathrm{R}, \mathrm{H}, 2020$ ).

Pada 24 Maret 2020, Menteri Pendidikan dan Kebudayaan Republik Indonesia mengeluarkan Surat Edaran Nomor 4 Tahun 2020 Tentang Kebijakan Pelaksanaan Pendidikan pada Masa Pandemi Covid-19, yang isinya menjelaskan bahwa proses belajar dilaksanakan di rumah melalui pembelajaran daring/ jarak jauh untuk tetap dapat melaksanakan dan memberikan pengalaman belajar untuk siswa ataupun siswa. Cara belajar jawark jauh dari rumah dapat memberikan pengalaman belajar dan memberikan kecakapan hidup saat pandemi Covid-19 (Permendikbud, 2020).

Covid-19 menyebabkan sekolah-sekolah di indoensia harus menerapkan pembelajaran secara online/ daring menggunakan berbagai platform aplikasi elekronik yang ada seperti Zoom meet, Google Meet, dan lain-lain. Penggunaan kelas belajar merupakan implementasi dari pembelajaran daring memalui aplikasi elektronik.
Dengan media ini, pendidik dapat mentransfer ilmu pengetahuan dalam pembelajaran. Pemebelajaran selain memakai aplikasi di atas dalam pembelajaran, guru dan siswa juga sering menggunakan aplikasi WhatsApp karena dinilai I ebih mudah (Rachmawati, et.al, 2020).

Pelaksanaan pembelajaran daring atau jarak jauh ini, menuntut siswa dan guru untuk memiliki akses jaringan internet yang baik. Salah satu faktor penghambat pembelajaran daring, pertama, masih banyak daerah-daerah yang tidak memiliki akses internet yang baik, sehingga hal tersebut menjadi salah satu kendala dalam pelaksanaan pembelajaran. Kedua, banyak siswa ataupun orang tua siswa belum paham dalam mengoperasikan beberapa aplikasi pembelajaran, seperti zoom meet, google meet dan lain-lain. Ketiga, tidak semua siswa atau orang tua siswa memiliki HP android untuk menggunakan aplikasi pembelajaran daring (Sulha, 2020). Keempat, kecenderungan anak-anak semakin tinggi untuk bermain game dari pada menggunakan Handphone untuk belajar.

Untuk mengatasi hal tersebut, beberapa sekolah menerapkan 3 metode yaitu metode daring, luring, dan home visit. Metode pembelajaran tatap muka (luring ataupun home visit) disekolah/ rumah hanya dilakukan 1 sampai 2 kali pertemuan dalam seminggu dan tetap memperhatikan protokol kesehatan. Pembelajaran luring (tatap muka) dilakukan dengan cara membagi anak dalam beberapa kelompok, tiap kelompok terdiri dari 4-5 siswa. Untuk siswa yang rumahnya berdekatan bisa bergabung menjadi 1 kelompok (maksimal 5 siswa dalam 1 kelompok), dan guru mendatangi kelompok siswa untuk belajar dengan 
diharapkan siswa lebih memahami mengenai materi pembelajaran (Malyana, 2020).

Terlebih lagi dalam pembelajaran Matematika di SD yang mengharuskan untuk pembelajaran tatap muka, matematika merupakan pelajaran yang mebahasa bagaimana berpikir logis, berpikir sistematis dan berpikir kritis dalam memecahkan masalah kehidupan sehari-hari (Novianingsih, 2016). Matematika sebagai ilmu dasar memiliki peranan yang sangat penting bagi kehidupan manusia terutama dalam usaha pengembangan Ilmu Pengetahuan dan Teknologi (IPTEK), karena matematika bukan hanya dibutuhkan sebagai alat berhitung pasif. Ini berarti bahwa aspek terapan maupun aspek penalarannya juga mempunyai peranan yang sangat penting dalam upaya meningkatkan teknologi (Rora, 2019).

Pembelajaran Matematika sangat berguna dalam mengatasi persoalan yang ada dikehidupan sehari-hari. Supaya peserta didik mempunyai kemampuan dalam menyelesaikan permasalahan yang mencakup kemampuan memahami masalah, merancang model matematika, mengerjakan model dan menafsirkan solusi yang didapatkan. Semua itu merupakan tujuan dari pembelajaran matematika di sekolah yang harus dimiliki dan dimengerti oleh peserta didik (Arief, 2018), sehingga sangat dibutuhkan cara pembelajaran yang baik untuk memenuhi sasaran pembelajaran matematika tersebut. Tanpa adanya aktivitas pembelajaran yang baik, maka partisipasi peserta didik bertindak secara aktif di dalam proses pembelajaran sulit tercipta. Oleh sebab itu, dalam pembelajaran matematika memerlukan strategi pembelajaran yang baik dan tepat (Fajri, 2010).

Pembelajaran Matematika harus menekankan pada pemberian pengalaman secara langsung kepada peserta didik untuk mengembangkan kompetensi yang dimilikinya, dan pada akhirnya mereka menemukan sendiri konsep materi pelajaran yang sedang dipelajarinya (Wijayanti, 2019). Selain itu pembelajaran Matematika diarahkan untuk dapat memberi pengalaman langsung sehingga dapat membantu peserta didik untuk memperoleh pemahaman yang lebih mendalam (Fajri, 2010).

Berdasarkan hasil pengamatan tentang pelaksanaan pembelajaran pada masa panemi Covid-19 di SD Negeri Wonosuko 2 Bondowoso, bahwa pelaksanaan menggunakan luring. Yaitu guru mendatangi kelompok belajar siswa, kelompok belajar sudah dibentuk oleh guru dan siswa dengan anggota kelompoknya terdiri dari 4 sampai 5 siswa. Dan pelaksanaan pembelajaran secara luring ini dilaksanakan pertemuan 2 kali dalam seminggu pada setiap kelompok. Terutama siswa kelas VI adalah siswa akhir untuk mempelajari materi khususnya Matematika yang lebih lengkap dan dirasa sulit, karena menuntut siswa untuk belajar berpikir logis, berpikir sistematis dan berpikir kritis yang tidak lepas dari berhitung menggunakan angka.

Berdasarkan uraian di atas, maka dilakukan penelitian untuk untuk mengetahui dan memahami tentang efektifitas pembelajaran luring mata pelajaran Matematikasiswa Kelas 6 SDN Wonosuko 2 Bondowoso.

\section{Metode}

Metode penelitian yang digunakan adalah metode deskriptif-kualitatif, dengan penjelasan deskriptif oleh peneliti yang melaksanakan penelitian selama 1 bulan yaitu mulai tanggal 15 Februari 2021 sampai 15 maret 2021 di SDN Wonosuko 2 Bondowoso dengan menggunakan teknik survey (Czauderna, A., \& Guardiola, 2019). Menurut Moleong, dengan menggunakan metode deskriptif berarti peneliti menganalisa data yang dikumpulkan dapat berupa kata-kata, gambar dan bukan angka-angka. Data tersebut bisa berasal dari naskah wawancara, catatan lapangan, foto, video tape, dokumen pribadi, catatan atau memo dan dokumen resmi lainnya (Moleong, 2010). berdasarkan pengertian diatas, dapat jilaskan bahwa penelitian ini menggunakan metode deskriptif, dengan melakukan analisa catatan lapangan yang dilaksanakan selama kurung kurang lebih 1 bulan serta dokumentasi berupa foto dan memo yang di dapat di lapangan pada saat penelitian berlangsung. Dengan cara pengumpulan data lapangan, peneliti dapat memperoleh hasil yang baik serta dapat menjelaskan efektifitas pembelajaran luring pada mata pelajaran Matematika saat pandemi Covid-19.

Untuk memperoleh data yang valid dan dapat dipertanggung jawabkan kebenarannya, penelitian ini menggunakan metode observasi, interview dan dokumentasi. Penelitian dilaksanakan pada semester Genap Tahun Pelajaran 2020/ 2021 di SDN Wonosuko 2 Bondowoso Jawa Timur. Instrumen penelitian yang digunakan adalah observasi (pengamatan pelaksanaan pembelajaran luring), angket dan wawancara. Sampel yang diambil adalah guru dan siswa kelas 6 SDN Wonosuko 2 Bondowoso.

Penelitian ini menggunakan Teknik Pengumpulan data sebagai berikut: 
a. Angket/ Kuesioner

Angket diberikan kepada siswa. Angket yang diberikan terdiri dari 6 pernyataan dengan opsi jawaban iya dan tidak. Adapun indikator dari angket tersebut terdiri dari enam item pernyataan. Adapun pernyataan dari setiap indikator angket disajikan pada Tabel 1 di bawah ini.

Tabel 1. Angket Umpan Balik Efektifitas Pembelajaran Luring pada Mata Pelajaran Matematika Siswa Kelas 6 SDN Wonosuko 2 Bondowoso

\begin{tabular}{|c|c|c|c|c|}
\hline \multirow{2}{*}{ Indikator } & \multirow{2}{*}{ No. Item } & \multirow{2}{*}{ Pernyataan } & \multicolumn{2}{|c|}{ Tanggapan } \\
\hline & & & Iya & Tidak \\
\hline \multirow{6}{*}{$\begin{array}{l}\text { Efektifitas } \\
\text { pembelajaran luring } \\
\text { pada mata pelajaran } \\
\text { Matematika }\end{array}$} & 1 & $\begin{array}{l}\text { Materi pembelajaran yang disampakan } \\
\text { dengan secara luring sangat jelas. }\end{array}$ & & \\
\hline & 2 & $\begin{array}{l}\text { Belajar dengan menggunakan luring } \\
\text { membuat saya lebih paham terhadap } \\
\text { materi (Matematika). }\end{array}$ & & \\
\hline & 3 & $\begin{array}{l}\text { Saya cepat memahami materi } \\
\text { (Matematika) melalui pembelajaran } \\
\text { luring dibandingkan dijelaskan secara } \\
\text { online/ daring. }\end{array}$ & & \\
\hline & 4 & $\begin{array}{l}\text { Saya sangat suka dengan pembelajaran } \\
\text { menggunakan secara luring. }\end{array}$ & & \\
\hline & 5 & $\begin{array}{l}\text { Saya sangat minat mengikuti } \\
\text { pembelajaran secara luring }\end{array}$ & & \\
\hline & 6 & $\begin{array}{l}\text { Dengan menggunakan pembelajaran } \\
\text { luring, memotivasi saya untuk } \\
\text { mengikuti pembelajaran luring lebih } \\
\text { aktif lagi. }\end{array}$ & & \\
\hline
\end{tabular}

b. Interview (wawancara)

Interview atau wawancara adalah suatu percakapan, tanya jawab lisan antara dua orang atau lebih yang duduk berhadapan secara langsung dengan tujuan untuk memperoleh informasi aktual, untuk menaksir dan menilai kepribadian individu, atau untuk tujuan-tujuan terpenting (Sugiono, 2007). Wawancara dilakukan kepada guru dan siswa sebagai pendukung yang memperkuat data. Pedoman wawancara seperti Tabel 2 di bawah ini:

Tabel 2. Pedoman Wawancara Umpan Balik Efektifitas Pembelajaran Luring pada Mata Pelajaran Matematika Siswa Kelas 6 SDN Wonosuko 2 Bondowoso

\begin{tabular}{|c|c|c|}
\hline Indikator & No. Item & Pertanyaan \\
\hline \multirow{6}{*}{$\begin{array}{c}\text { Efektifitas pembelajaran } \\
\text { luring pada mata } \\
\text { pelajaran Matematika }\end{array}$} & 1 & $\begin{array}{l}\text { Bagaimana tanggapan Anda dalam mengikuti } \\
\text { pembelajaran luring? Suka atau tidak (jelaskan) }\end{array}$ \\
\hline & 2 & $\begin{array}{l}\text { Apakah materi yang disampaikan dalam pembelajaran } \\
\text { sudah jelas atau mengalami kendala? Kenapa demikian! }\end{array}$ \\
\hline & 3 & $\begin{array}{l}\text { Apakah materi yang disampaikan dalam pembelajaran } \\
\text { mudah difahami? Jelaskan }\end{array}$ \\
\hline & 4 & $\begin{array}{l}\text { Apakah materi yang disampaikan sesuai dengan tujuan } \\
\text { pembelajaran? }\end{array}$ \\
\hline & 5 & $\begin{array}{l}\text { Apakah materi yang disampaikan sesuai dengan alokasi } \\
\text { waktu yang ditentukan? }\end{array}$ \\
\hline & 6 & $\begin{array}{l}\text { Apakah anda merasa puas mengikuti pembelajaran } \\
\text { luring? Jelaskan }\end{array}$ \\
\hline
\end{tabular}

c. Observasi (pengamatan)

Observasi merupakan metode pengumpulan data yang digunakan untuk menghimpun data penelitian melalui pengamatan langsung dan pengindraan. Dalam hal ini, pengamatan dila- kukan saat proses pembelajaran luring Mata Pelajaran Matematika pada siswa kelas VI SDN Wonosuko 2 Bondowoso. Lembar observasi yang digunakan menggunakan 11 item pernyataan tentang pembelajaran luring pada mata pelajaran 
Matematika. Pengamatan akan menjadi alat pengumpulan data yang baik, jika:

1) Mengabdi kepada tujuan penelitian

2) Direncanakan secara sistematik

3) Dicatat dan dihubungkan dengan proposisiproposisi yang umum
4) Dapat dicek dan dikontrol validitas, reliabilitas dan ketelitiannya (Achmadi, Abu, 2009).

Adapun pedoman Observasi Efektifitas Pembelajaran Luring seperti Tabel 3 di bawah:

Tabel 3. Pedoman Observasi Efektifitas Pembelajaran Luring pada Mata Pelajaran Matematika Siswa Kelas 6 SDN Wonosuko 2 Bondowoso

\begin{tabular}{|c|c|c|c|c|}
\hline \multirow{2}{*}{ Indikator } & \multirow{2}{*}{$\begin{array}{l}\text { No. } \\
\text { Item }\end{array}$} & \multirow{2}{*}{ Kegiatan } & \multicolumn{2}{|c|}{ Dilaksanakan } \\
\hline & & & Ya & Tidak \\
\hline \multirow{12}{*}{$\begin{array}{l}\text { Efektifitas pembelajaran luring } \\
\text { pada mata pelajaran Matematika }\end{array}$} & 1 & $\begin{array}{l}\text { Menyampaikan kompetensi (tujuan) } \\
\text { pembelajaran sesuai RPP yang sudah dibuat. }\end{array}$ & & \\
\hline & 2 & $\begin{array}{l}\text { Jumlah kehadiran/ partisipasi siswa dalam } \\
\text { pelaksanaan pembelajaran luring (lebih dari } \\
80 \% \text { dari masimal } 5 \text { siswa per kelompok) }\end{array}$ & & \\
\hline & 3 & Memotivasi siswa untuk giat dalam belajar & & \\
\hline & 4 & $\begin{array}{l}\text { Memberi kesempatan kepada siswa untuk } \\
\text { bertanya }\end{array}$ & & \\
\hline & 5 & $\begin{array}{l}\text { Menumbuhkan keceriaan dan antusisme siswa } \\
\text { dalam belajar }\end{array}$ & & \\
\hline & 6 & $\begin{array}{l}\text { Memberikan kesempatan kepada siswa untuk } \\
\text { menyampaikan hasil pekerjaannya }\end{array}$ & & \\
\hline & 7 & $\begin{array}{l}\text { Menunjukkan sikap terbuka terhadap respon } \\
\text { siswa. }\end{array}$ & & \\
\hline & 8 & $\begin{array}{l}\text { Melaksanakan pembelajaran sesuai dengan } \\
\text { waktu yang telah dialokasikan }\end{array}$ & & \\
\hline & & $\begin{array}{l}\text { Melakukan penilaian akhir sesuai dengan } \\
\text { kompetensi (tujuan) yang diharapkan }\end{array}$ & & \\
\hline & 9 & & & \\
\hline & 10 & $\begin{array}{l}\text { Melakukan refleksi pembelajaran dengan } \\
\text { melibatkan siswa }\end{array}$ & & \\
\hline & 11 & Melaksanakan tindak lanjut & & \\
\hline
\end{tabular}

Teknik analisis data yang digunakan dalam penelitian ini adalah teknik deskriptif kualitatif yaitu penelitian yang dilakukan dengan cara menggambarkan keadaan atau fenomena di lapangan yang dipilih secara sistematis untuk memperoleh kesimpulan dengan menggunakan bahasa yang mudah dicerna atau mudah difahami oleh masyarakat umum (Moleong, 2010). Prosedur analisis data yang digunakan dalam penelitian ini, yaitu:

\section{1) Reduksi Data}

Reduksi data termasuk dalam kategori pekerjaan analisis data. Data yang berupa catatan lapangan (field notes), jumlahnya yang cukup banyak, untuk itu maka perlu dicatat secara teliti dan rinci. Mereduksi data adalah merangkum, memilih hal-hal pokok, memfokuskan pada hal-hal yang penting, dan dicari tema polanya. Denagan demikian data yang telah direduksi akan memberikan gambaran yang lebih jelas dan mempermudah peneliti untuk melakukan pengumpulan data selanjutnya, dan mencarinya bila diperlukan (Mills, 1992).

\section{2) Display Data (penyajian data)}

Hasil reduksi perlu "didisplay" secara tertentu untuk masing-masing pola, kategori, tema yang hendak difahami dan mengerti persoalannya (Farida, 2017). Display data dapat membantu peneliti untuk melihat gambaran keseluruhan atau bagian-bagian tertentu dari hasil penelitian. Dalam penelitian ini, penyajian data dilakukan dalam bentuk uraian singkat, bagan dan sebagainya yang bersifat naratif.

\section{3) Mengambil Kesimpulan}

Kesimpulan awal yang dikemukakan masih bersifat sementara, dan akan berubah apabila 
tidak ditemukan bukti-bukti kuat yang mendukung pada tahap pengumpulan data berikutnya (Elfrida Ita, 2018). Dengan demikian, kesimpulan dalam penelitian kualitatif dapat menjawab rumusan masalah yang dirumuskan sejak awal dan akan berkembang setelah penelitian berada di lapangan.

\section{Hasil dan Pembahasan}

Pelaksanaan pembalajaran di SDN Wonosuko 2 Bondowoso dilaksanakan luring, pelaksanaan pembelajaran secara luring dikaksanakan selama 3-4 kali selama 1 minggu, dan sisanya dilaksanakan secara daring. Daring hanya dilakukan ketika siswa diberikan tugas dan dan pengumpulan tugas, atau jika siswa mengalami kendala belajar bisa melakukan tanya jawab melalui grop WA.

Penelitian ini difokuskan pada kegiatan pembalajaran luring, yaitu efektifitas pembelajaran luring mata pelajaran matematika. Dipilihnya materi Matematika karena berdasarkan pengamatan di lapangan sebelum pelaksanaan penelitian, siswa mengalami kendala pemahaman materi atau materi Matematika dianggap paling sulit oleh siswa, sehingga sangat memerlukan ketelatenan dan strategi guru dalam menyampaikan materi Matematika.

Langkah pertama peneliti dalam melaksanakan penelitian di SDN Wonosuko 2 ini, meminta izin kepada Lembaga yaitu Kepala Sekolah dan guru kelas VI di SDN Wonosuko 2. Setelah itu peneliti langsung terjun ke lapangan untuk mengambil data yang sudah direncanakan terlebih dahulu, yaitu menggunakan isntrumen angket/ kuesioner, wawancara dan observasi selama kegiatan pembelajaran berlangsung secara luring.

Hasil penelitian tentang Efektifitas Pembelajaran Luring pada Mata Pelajaran Matematika Siswa Kelas 6 SDN Wonosuko 2 Bondowoso, dapat dijabarkan sebagai berikut:

a. Hasil Angket tentang Efektifitas Pembelajaran Luring pada Mata Pelajaran Matematika Siswa Kelas 6 SDN Wonosuko 2 Bondowoso.

Lembar angket yang sudah disiapkan oleh peneliti, disebar luaskan kepada siswa untuk diisi sesuai yang mereka alami selama kegiatan pembelajaran luring pada mata pelajaran Matematika. Siswa yang mengerjakan lembar angket sebanyak 15 siswa. Hasil sebaran angket sebanyak 15 , yang dihasilkan sesuai gambar diagram di bawah ini:

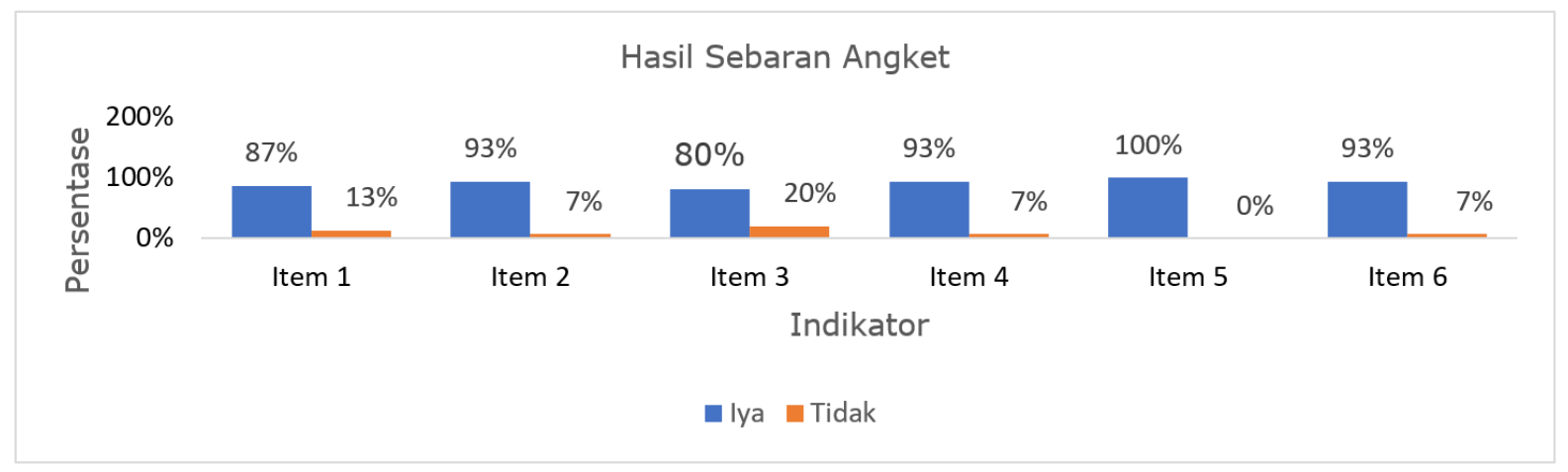

Diagram 1. Hasil Angket Efektifitas Pembelajaran Luring

Berdasarkan diagram 1 di atas, dapat dijelaskan bahwa:

Materi pembelajaran yang dilaksanakan secara luring (luar jaringan/ tatap muka langsung) sangat jelas diperoleh tanggapan 15 siswa kelas 6 SDN Wonosuko 2 Bondowoso sebagai berikut:

Item 1. Siswa memahami materi pembelajaran yang disampakan dengan secara luring sangat jelas, diperoleh tanggapan 13 siswa dengan jawaban iya dan 2 siswa dengan jawaban tidak, sehingga diperoleh persentase $87 \%$ jawaban iya dan $13 \%$ jawaban tidak.

Item 2. Belajar dengan menggunakan luring membuat saya lebih paham terhadap materi
(Matematika), diperoleh tanggapan 14 siswa dengan jawaban iya dan 1 siswa dengan jawaban tidak, sehingga diperoleh persentase 93\% jawaban iya dan $7 \%$ jawaban tidak

Item 3. Saya cepat memahami materi (Matematika) melalui pembelajaran luring dibandingkan dijelaskan secara online/ daring, diperoleh tanggapan 12 siswa dengan jawaban iya dan 3 siswa dengan jawaban tidak, sehingga diperoleh persentase $80 \%$ jawaban iya dan $20 \%$ jawaban tidak

Item 4. Saya sangat suka dengan pembelajaran menggunakan secara luring, diperoleh tanggapan 14 siswa dengan jawaban iya dan 1 siswa dengan 
jawaban tidak, sehingga diperoleh persentase $93 \%$ jawaban iya dan $7 \%$ jawaban tidak

Item 5. Tanggapan siswa tentang saya sangat minat mengikuti pembelajaran secara luring, diperoleh tanggapan 15 siswa dengan jawaban iya dan 0 siswa dengan jawaban tidak, sehingga diperoleh persentase $100 \%$ jawaban iya dan $0 \%$ jawaban tidak.

Item 6. Hasil angket siswa dengan menggunakan pembelajaran luring, memotivasi saya untuk mengikuti pembelajaran luring lebih aktif lagi, diperoleh tanggapan 14 siswa dengan jawaban iya dan 1 siswa dengan jawaban tidak, sehingga diperoleh persentase $93 \%$ jawaban iya dan $7 \%$ jawaban tidak

Rata-rata persentase dari ke enam item di atas adalah adalah $91 \%$ jawaban iya dan $9 \%$ jawaban tidak, sehingga dapat disimpulkan Efektifitas Pembelajaran Luring pada Mata Pelajaran Matematika Siswa Kelas 6 SDN Wonosuko 2 Bondowoso sangat efektif dalam membantu siswa dalam memamahami materi dengan baik.

b. Hasil Wawancara tentang Efektifitas Pembelajaran Luring pada Mata Pelajaran Matematika Siswa Kelas 6 SDN Wonosuko 2 Bondowoso.

Selain menggunakan sebaran angket, peneliti juga menggunakan wawanacara kepada beberapa siswa untuk mendapatkan hasil yang lebih valid tentang tanggapan siswa sebagai penunjang hasil penelitian. Siswa yang diwawancarai dipilih secara random kepada 10 siswa kelas 6 SDN Wonosuko 2 Bondowoso. Yaitu;

1) Rata-rata tanggapan siswa dalam mengikuti pembelajaran Luring pada Mata Pelajaran Matematika merasa suka dan senang, karena siswa mengalami tatap muka langsung, sehingga jika ada materi yang belum difahami bisa ditanyakan langsung ke gurunya.

2) Rata-rata tanggapan siswa tentang materi yang disampaikan dalam pembelajaran sudah jelas, meskipun kadang-kadang ada kendala karena alokasi waktu dalam belajar terbatas hanya 2 kali tatap muka dalam seminggu, yang biasanya dilaksanakan tatap muka 6 hari dalam seminggu sekarang malah dilaksanakan 2 hari dalam seminggu.

3) Rata-rata tanggapan siswa tentang materi yang disampaikan dalam pembelajaran mudah difahami, karna pembelajaran bertatap langsung antara guru dan siswa, namu kendalanya tidak semua materi dipelajari secara maksimal karena keterbatasan waktu pembelajaran luring.
4) Tanggapan siswa tentang materi yang disampaikan sesuai dengan tujuan pembelajaran, karena sebelum pelaksanaan pembelajaran, guru sudah menyampaikan tujuan pembelajarannya.

5) Tanggapan siswa tentang materi yang disampaikan kurang sesuai dengan alokasi waktu, disebabkan karena adanya pandemic Covid-19 sehingga pembelajaran tidak berjalan secara normal lagi. Pembelajaran luring menyebabkan penjelasan materi sedikit ( 2 kali tatap muka dalam seminggu) dan pemberian tugas tambah banyak (lebih banyak belajar mandiri di rumah).

6) Siswa merasa puas mengikuti pembelajaran Luring pada Mata Pelajaran Matematika karena siswa tetap muka dan dijelaskan langsung, meskipun ada keterbatasan waktu dalam pelaksanaan pembelajaran luring.

Berdasarkan hasil wawancara di atas, dapat disimpulkan bahwa Pembelajaran Luring pada Mata Pelajaran Matematika dapat Meningkatkan Efektifitas Belajar Siswa di Tengah Pandemi Covid-19 meskipun banyak kendala terutama alokasi waktu pelaksanaan pembelajaran.

c. Hasil observasi tentang Efektifitas Pembelajaran Luring pada Mata Pelajaran Matematika Siswa Kelas 6 SDN Wonosuko 2 Bondowoso. Kegiatan observasi dilakukan ketika pelaksanaan pembelajaran berlangsung, yaitu guru dan siswa melaksanakan pembelajaran secara luring pada mata pelajaran Matematika. Adapun hasil observasi terhadap kegiatan pembelajaran siswa kelas VI SDN Wonosuko 2 Bondowoso, bahwa semua komponen terlaksana semua dan dapat berjalan dengan baik, meskipun banyak kendala terutama waktu pelaksanaan pembelajaran secara luring terbatas antara guru dan siswa. Dapat disimpulkan bahwa Efektifitas Pembelajaran Luring pada Mata Pelajaran Matematika dapat dijadikan alternatif dalam pelaksanaan pembelajaran di Tengah Pandemi Covid-19. Sehingga sekolahsekolah yang mengalami kesulitan dalam pembelajaran daring tetap dapat melaksanakan pembelajaran dengan baik.

\section{Kesimpulan}

Berdasarkan pembahasan di atas, dapat disimpulkan bahwa pada pelaksanaan pembelajaran masa pandemic Covid-19, dengan menggunakan 3 strategi yaitu daring, luring, dan home 
visit. Pelaksanaan pembelajaran daring, menuntut siswa dan guru untuk memiliki akses jaringan internet yang baik. Namun tidak semua daerah/ sekolah selalu tercover oleh jaringan internet yang baik, tidak semua orang tua atau siswa memiliki dan mampu mengoperasikan beberapa aplikasi pembelajaran daring. Dan dilihat dari pembelajaran matematika mebahas bagaimana berpikir logis, berpikir sistematis dan berpikir kritis dalam memecahkan masalah kehidupan sehari-hari, sehingga pembelajaran matematika sangat perlu bimbingan dan arahan langsung dari guru. Solusi pembelajaran yang baik saat pandemic Covid-19 adalah tetap mengadakan pembelajaran yaitu dengan pebelajaran luring (tatap muka) antara guru dan siswa namun tetap memperhatikan protocol kesehatan.

Hasil angket, wawancara dan observasi menunjukkan bahwa pembelajaran secara luring dapat meningkatkan efektifitas pembelajaran Matematika pada siswa kelas VI SDN Wonosuko 2 Bondowoso dan dapat membantu siswa dalam memamahami materi dengan baik meskipun masih ditemui banyak kendala. Sehingga hasil penelitian ini dapat disimpulkan bahwa pembelajaran luring lebih efektif dan efesien dilaksanakan di SDN Wonosuko 2 Bondowoso terutama materi pembelajaran matematika pada masa pandemic Covid-19.

\section{Daftar Pustaka}

Achmadi, Abu, . dan Cholid Narbuko. (2009). Metodologi Penelitian. PT. Bumi Aksara.

Aji, R, H, S. (2020). Dampak COVID-19 pada pendidikan di Indonesia: sekolah, keterampilan dan proses pembelajaran. Salam: Jurnal Sosial Dan Budaya Syar'i., 7(5), 395-402. http://journal.uinjkt.ac.id/ index.php/salam/article/view/15314

Arief, A. R. (2018). Strategi Belajar Mengajar Matematika. Syiah Kuala University Press.

Czauderna, A., \& Guardiola, E. (2019). The Gameplay Loop Methodology as a Tool for Educational Game Design. Electronic Journal of E-Learning, 17(3), 207-221. https://doi.org/10.34190/JEL.17.3.004

Elfrida Ita. (2018). Manajemen Pembelajaran Pendidikan Anak Usia Dini di TK Rutosoro Kecamatan Golewa Kabupaten Ngada Flores Nusa Tenggara Timur. Jurnal Dimensi Pendidikan Dan Pembelajaran, 6(1), 45-52.
Fajri, Z. (2010). Pembelajaran Kooperatif dengan Menerapkan Teori Brunner Pokok Bahasan Keliling dan Luas Bangun Datar Kelas IVA SD Negeri Tamanan 2 Tahun Ajaran 2009/2010. Universitas Jember.

Farida, S. (2017). Pengelolaan Pembelajaran Paud. Wacana Didaktika, 5(02), 189. https://doi. org/10.31102/wacanadidaktika.v5i02.63

Halal, S. A. R. (2020). Dampak Covid-19 pada Pendidikan di Indonesia: Sekolah, Keterampilan, dan Proses Pembelajaran. Jurnal Sosial Dan Budaya Syar-I, 7(5), 397-400.

Malyana, A. (2020). Pelaksanaan Pembelajaran Daring Dan Luring Dengan Metode Bimbingan Berkelanjutan Pada Guru Sekolah Dasar Di Teluk Betung Utara Bandar Lampung. 2(1), 67-76. p-ISSN: 2685-2519 eISSN: 2715-6028.

Mastura, \& Santaria, R. (2020). Dampak Pandemi Covid-19 terhadap Proses Pengajaran bagi Guru dan Siswa. Jurnal Studi Guru Dan Pembelajaran, 3(2), 289-295. https://ejournal.my.id/jsgp/article/view/29

Mills, H. (1992). Metodologi Penelitian Kualitatif. Renika Cipta.

Moleong, L. J. (2010). Metodologi Penelitian Kualitatif. In Metodologi Penelitian Kualitatif. Remaja Rosdakarya.

Novianingsih, H. (2016). Pendekatan Pembelajaran Aktif, Kreatif, Efektif, Dan Menyenangkan Dalam Pembelajaran Matematika Sekolah Dasar. Jurnal Pendidikan Guru Sekolah Dasar, 1(1), 1-11. https://doi. org/10.17509/jpgsd.v1i1.9063

Permendikbud. (2020). Surat Edaran Nomor 4 Tahun 2020 tentang Pelaksanaan Kebijakan Pendidikan dalam Masa Darurat Penyebaran Coronavirus Disease (COVID-19). Kementerian Pendidikan dan Kebudayaan. https://www.google. com/search?q=agenda + pendidikan + $2020 \& o q=$ agenda $+\& a q s=$ chrome 0 . 69i59j69i57j016.2382j0j7\&sourceid= chrome\&ie $=$ UTF-8

Rachmawati, Y., Ma'arif, M., Fadhillah, N., Inayah, N., Ummah, K., Siregar, M. N. F., \& Auliyah, A. (2020). Studi Eksplorasi Pembelajaran Pendidikan IPA Saat Masa Pandemi COVID-19 di UIN Sunan Ampel Surabaya. Indonesian Journal of Science Learning, 1(1), 32-36. 
Rora, R. W. (2019). Pembelajaran Matematika untuk Calon Guru MI/SD. Pustaka pelajar. Sugiono. (2007). Metode Penelitian Kuantitatif Kualitatif dan R\&D. Alfabeta.

Sulha. (2020). Penerapan Montessori dalam Pembelajaran Matematika Melalui Luring Sebagai Alternatif Masa Pandemi. Prismatika: Jurnal Pendidikan Dan Riset Matematika, 3(1), p-ISSN: 2654-6140, e-ISSN: 2656-4181. http://ejurnal. budiutomomalang.ac.id/index.php/ prismatika
Wijayanti, E. (2019). Upaya Meningkatkan Peran Aktif Siswa dalam Pembelajaran Matematika dengan Menggunakan Model Mencari Pasangan (Make A Match) Kelas XI IPS MA Salafiyah Wonoyoso Kabupaten Kebumen Tahun Ajaran 2018/ 2019. Jurnal Pengembangan Pembelajaran Matematika, 1(2), 1-10. 